\title{
The Differentiation of Tobacco Smoke Condensates on the Basis of Reducing Properties
}

\author{
by $M . H$. Bilimoria and $M$. A. Nisbet \\ Imperial Tobacco Products Limited, Research Department, Montreal P. Q., Canada
}

\section{INTRODUCTION}

The reducing substances in tobacco smoke have come under intermittent scrutiny over a considerable number of years. Shmuk (7) in 1939 related the amount of reducing substances in smoke to smoke quality and more recently Wickham et al. (xo) described an automated procedure using potassium ferricyanide to measure dialysable reducing substances in total particulate matter (TPM). Hagopian and Rosencrantz have employed blue tetrazolium to measure the reducing properties of smoke and have used this reagent to estimate the extent of retention of smoke in the respiratory tract (4) and also to differentiate between cigarette types (3).

Our interest in the reducing property of cigarette smoke was the result of our studies on the effect of smoke on the subcellular components of mammalian cells. While studying the effect of cigarette smoke on enzyme activities using cytochrome $c$ as electron acceptor, we found that cigarette smoke alone could chemically reduce the cytochrome. We considered this reaction of smoke with a physiological electron acceptor in the mitochondrial electron transport system, of significarice, as this property of cigarette smoke could theoretically affect the energy producing mechanism of the cell. Further, the reduction of cytochrome $c$ showed promise as a means of assaying the biological activity of cigarette smoke. However, a routine test procedure using cytodirome $c$ was considered unattractive due to appearance of turbidity at higher smoke concentrations and due to the expensive nature of the reagent. Hence the artificial electron acceptor dichlorophenolindophenol (DCIP) was tested and it was found to be rapidly reduced. Its absorption maximum at $600 \mathrm{~nm}$ which eliminates interference from chromophores in the smoke and the large molar absorptivity make it a highly suitable reagent.

While this work was in progress Benedict and coworkers (1) described the effect of cigarette smoke on DCIP along with some preliminary investigations into the nature and stability of the reducing substances and have recently published further details of reaction of smoke with other redox compounds (2).

\footnotetext{
- Received for publication: 10rh December, 1970.
}

In this laboratory DCIP has been used to examine the reducing properties of smoke from different cigarette brands. A similar test has been applied to tobacco burnt in cigar form and in pipes. Further experiments have been carried out on the nature and stability of the reducing substances, and a brief comparison has been made of the rates of reduction by smoke of DCIP and cytochrome $c$.

\section{MATERIALS AND METHODS}

\section{Smoking Procedures}

Commercially available cigarettes and cigars were smoked under standard conditions which are designed to simulate human smoking. One $35 \mathrm{ml}$ puff of 2 -second duration was collected every minute using a suitable smoking machine. In determining the reducing activity of condensates, 5 cigarettes or 2 cigars of each brand were smoked to butt lengths of $30 \mathrm{~mm}$ and $50 \mathrm{~mm}$ respectively. In the case of pipe-smoking, one $35 \mathrm{ml}$ puff of 2-second duration was collected every to seconds and the tobaccos were smoked in $4 \mathrm{gm}$ quantities in stainless steel smoking pipes and employing a pipe tobacco smoking madhine designed in this laboratory. In the case of smoking cigar tobacco in pipes, it was found that $3 \mathrm{gm}$ was sufficient to fill the bowl.

The particulate matter was collected on weighed Cambridge pads and the gaseous phase, when needed, was trapped in spiral condensers cooled to $-70^{\circ} \mathrm{C}$. When whole smoke condensates were needed, the smoke was led directly into spiral condensers cooled as above. The Cambridge filter pads were weighed and extracted by homogenisation in $25 \mathrm{ml}$ of ethanol or buffer and fittered through glass wool. Condensates in spiral condensers were washed out using small aliquots of the solvent and the volume made up to $25 \mathrm{ml}$. In several studies the TPM collected on Cambridge pads was dried over $\mathrm{NaOH}$ pellets placed in an evacuated desiccator kept at $4^{\circ} \mathrm{C}$.

\section{Reduction of DCIP}

The change in absorbance at $6.00 \mathrm{~nm}$ when DCIP is reduced was used to measure the reducing property of the smoke. The assay was performed as follows: 
Into the reference and sample cuvettes $0.8 \mathrm{ml}$ of the Tris(hydroxymethyl)-aminomethane- $\mathrm{HCl}(\mathrm{Tris}-\mathrm{HCl})$ buffer, $\mathrm{pH} 8.0$, and $0.1 \mathrm{ml}$ of ${ }_{4} \times 10^{-4} \mathrm{M}$ DCIP were placed. The spectrophotometer was balanced, $0.1 \mathrm{ml}$ of ethanol added to the cuvette in the sample compartment, and the reaction initiated by adding $0.1 \mathrm{ml}$ of the appropriate smoke dilution to the cuvette in the blank compartment. An increase in absorbance was recorded as the DCIP in the blank compartment was reduced to its colourless form by the smoke condensate.

Since the rates are not linear with time, the reaction being second or higher order, the change in absorbance was measured in the first 15 seconds. Several dilutions were assayed for each condensate and the average rate was determined. The values recorded are generally the averages calculated from 3 separate experiments carried out on 3 different days. For the cigarette condensates an analysis of variance was performed and no significant differences were detected between dilutions, nor were there any significant day to day differences observed, thus enabling us to compare condensates tested at different times.

\section{Reduction of Cytochrome $c$}

The increase in absorption at $550 \mathrm{~nm}$ when cytochrome $c$ is reduced, was also used to measure the reducing property of smoke. The assay of cytochrome $c$ reduction was similar to that used for DCIP. Both blank and sample cuvettes contained $0.8 \mathrm{ml}$ of $0.05 \mathrm{M}$ Tris- $\mathrm{HCl}$ buffer, $\mathrm{pH} 8.0$, and $4 \times 10^{-6} \mathrm{M}$ cytochrome c, and the reaction was initiated by adding $0.1 \mathrm{ml}$ of the appropriate dilution of smoke condensate solution to the cuvette in the sample compartment and recording the increase in absorbance as described in the case of DCIP.

\section{RESULTS AND DISCUSSION}

\section{The Measurement of the Reduction of DCIP} and Cytochrome $c$

The increase in absorbance observed at $550 \mathrm{~nm}$ when cigarette smoke condensate was added to cytochrome c is typical of reduction of the cytochrome. This was confirmed by comparing a spectrum of smoke-reduced cytochrome $c$ to oxidised cytochrome $c$ when typical spectra of reduced and oxidised cytochrome $c$ were obtained (see Figure $x$ ). Reduction of DCIP by electron transfer was followed by noting the disappearance of the absorption peak at $600 \mathrm{~nm}$ as smoke reduced the dye to the colourless form.

Although it has not yet been determined which compounds in tobacco smoke condensates are involved in the reduction of these electron acceptors, nevertheless, the reaction is useful for the comparison of condensates once arbitrary units of reducing activity at fixed concentration of the electron acceptor under study are defined. A unit of reducing activity with DCIP has been defined as that amount which brings about an absorbance change of 1.0 per minute at $600 \mathrm{~nm}$ at ambient temperature $\left(20-22^{\circ} \mathrm{C}\right)$ in a $1 \mathrm{~cm}$ light path at an initial concentration of ${ }_{4} \times 10^{-5} \mathrm{M}$ DCIP.
Figure 1. Spectra of cytochrome c.

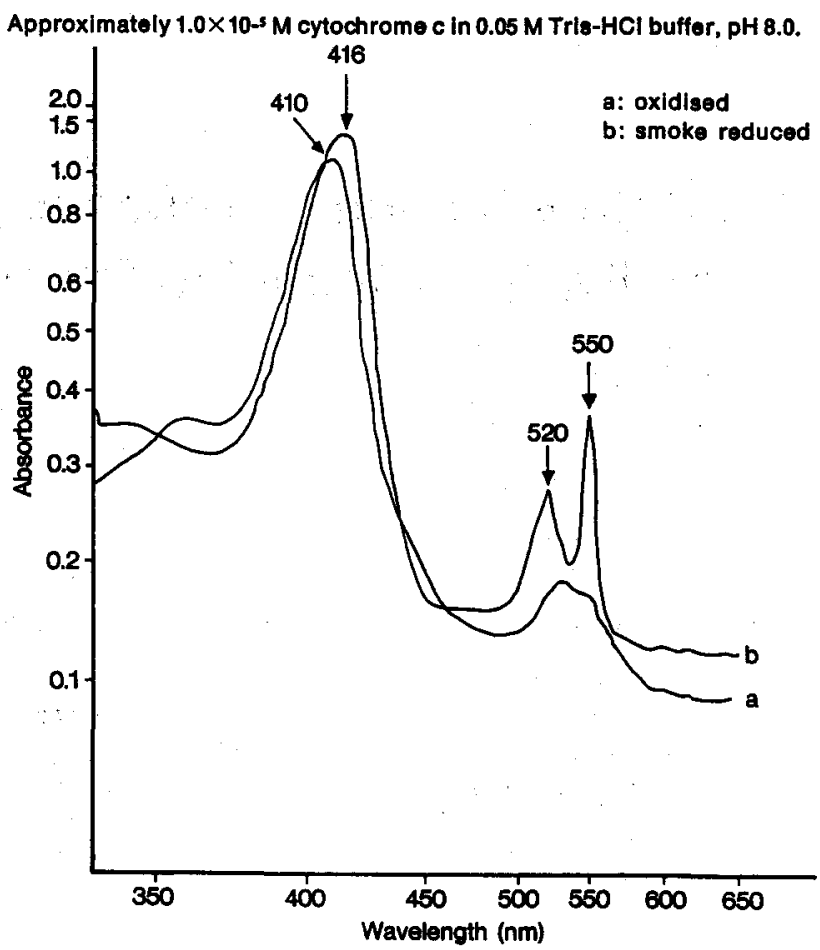

The reactions were carried out at $\mathrm{pH} 8.0$, which was found to be the most suitable. The extinction coefficient of oxidised DCIP was found to be $18.5 \times 10^{3} \mathrm{M}^{-1} \mathrm{~cm}^{-1}$ in Tris- $\mathrm{HCl}$ buffer at $\mathrm{pH} 8.0$, therefore, $I$ unit of DCIP reducing activity corresponds to reduction of 0.0541 micromole DCIP reduced per minute per $\mathrm{ml}$ of reaction mixture. Similarly, a unit of reducing activity with cytochrome $c$ has been defined as that amount which brings about an absorbance change of 1.0 per minute at $550 \mathrm{~nm}$ at ambient temperature in a $I \mathrm{~cm}$ light path at an initial concentration of ${ }_{4} \times \times_{10}^{-5} \mathrm{M}$ of cytochrome c. If an absorbance change of $18.5 \times 10^{3} \mathrm{M}^{-1} \mathrm{~cm}^{-1}$ is assumed between reduced and oxidised cytochrome c (5), a unit of cytochrome $c$ reducing activity corresponds to reduction of $0.054 \mathrm{I}$ micromole cytochrome $c$ reduced per minute per $\mathrm{ml}$ of reaction mixture. Specific activity in the case of both cytochrome $c$ and DCIP has been expressed as the number of units per mg particulate matter.

At constant smoke and electron acceptor concentrations it was observed that the cytochrome $c$ unit was about half the DCIP unit. When the reducing activity is expressed in terms of $\mu$ mole electron acceptor reduced per minute per $\mathrm{ml}$ of reaction mixture, it appears that the amount of cytochrome $c$ reduced is double that of DCIP. This is understandable when it is considered that DCIP is a two-electron and cytochrome $c$ a one electron acceptor. Consequently, if the reducing activity is expressed in terms of electron equivalents of these electron acceptors reduced per minute per $\mathrm{ml}$ of reaction mixture, the values obtained become similar. That these values are close can be explained in terms of the redox potentials of these two electron acceptors, which are very similar (9), and the same compounds in smoke condensate that reduce cytochrome $c$ should reduce DCIP. 
Table 1. Extraction and stability of DCIP reducing actlvilty.

\begin{tabular}{l|c|c|c|c}
\hline \multicolumn{1}{c|}{$\begin{array}{c}\text { Extraction } \\
\text { in }\end{array}$} & $\begin{array}{c}\text { Weight } \\
\text { of TPM } \\
\text { mg } \\
\text { (5 ciga- } \\
\text { rettes) }\end{array}$ & \multicolumn{3}{|c}{ Specific activity } \\
& $\begin{array}{c}\text { Initial } \\
\text { values }\end{array}$ & $\begin{array}{c}\text { After 24 } \\
\text { hrs. at } \\
20-22^{\circ} \mathrm{C}\end{array}$ & $\begin{array}{c}\text { After 48 } \\
\text { hrs. at } \\
20-22^{\circ} \mathrm{C}\end{array}$ \\
\hline Ethanol (pH 6.1) & 131.0 & 6.25 & 2.65 & 2.79 \\
PO4 buffer, pH 5.7 & 134.8 & 2.96 & 1.24 & 0.91 \\
-do-, pH 6.0 & 119.4 & 3.06 & 1.01 & 0.77 \\
-do-, pH 6.5 & 123.7 & 2.76 & 0.94 & 0.47 \\
-do-, pH 7.0 & 125.4 & 2.08 & 0.57 & 0.13 \\
-do-, pH 7.5 & 128.9 & 1.95 & 0.34 & 0.07 \\
\hline
\end{tabular}

\section{Extraction and Stability of Cigarette Smoke} Reducing Activity

Hagopian (3), who prepared ethanolic solutions of cigarette smoke, found that these solutions remained unchanged for 5 days, while Benedict et al. (1) who prepared aqueous solutions, reported that their solutions were unstable, being inactivated within 90 minutes. Preliminary results obtained in this laboratory have shown that when the particulate matter of cigarette smoke condensate collected on Cambridge pads is extracted with ethanol a larger amount of reducing activity is obtained than when the pads are extracted with $0.05 \mathrm{M}$ Tris- $\mathrm{HCl}$ buffer, $\mathrm{pH}$ 8.o. Also, the reducing activity is more stable when stored in ethanol solution than when stored in buffer.

Since in the above experiments, the buffer solutions were at $\mathrm{pH} 8.0$ and the ethanol solutions at $\mathrm{pH} 6.1-$ 6.2, the effect of $\mathrm{pH}$ of the buffer solution on the amount of reducing substances extracted and their stability was studied. From Table $I$ it will be seen that ethanol extraction not only gave the highest yield of reducing activity, but also produced the most stable solution. Buffers with acid $\mathrm{pH}$ were more suitable for extraction and gave more stable solutions than alkaline buffers. In other experiments air oxidation of these reducing compounds was attempted by shaking ethanolic solutions in air, and little loss in activity was found even after 5 hours of shaking. Refluxing ethanolic solutions for ten minutes did not result in an appreciable loss of activity.

Table 2. Reducing actlvitles of flue-cured and blended clgarette smoke condensates (molat TPM).

\begin{tabular}{ll|c|c|c}
\hline $\begin{array}{c}\text { Brand } \\
\text { No. }\end{array}$ & $\begin{array}{c}\text { Weight } \\
\text { of TPM } \\
\text { per cigarette } \\
\text { (mg) }\end{array}$ & \multicolumn{2}{|c}{$\begin{array}{c}\text { Reducing activity } \\
\text { Units per } \\
\text { cigarette }\end{array}$} & $\begin{array}{r}\text { Specific } \\
\text { activity }\end{array}$ \\
\hline Flue-cured & & & & \\
Brand & 1 & 23.26 & 147.1 & 6.32 \\
& 2 & 20.21 & 130.7 & 6.47 \\
& 3 & 20.77 & 128.4 & 6.17 \\
& 4 & 33.77 & 181.8 & 5.38 \\
& 5 & 8.49 & 51.6 & 6.07 \\
Blended & & & & 4.28 \\
Brand & 1 & 17.8 & 76.5 & 3.84 \\
& 2 & 17.6 & 58.3 & 3.60 \\
\hline
\end{tabular}

Examination of Cigarette Tobacco and Cigarette Ash for Reducing Activity

Ethanol and water extracts of cigarette tobacco prepared by soaking overnight $10 \mathrm{~g}$ of tobacco in $200 \mathrm{ml}$ of solvent, blending $I$ minute in a Waring blendor and filtering, did not show any DCIP reducing activity. Nor did an ash solution show activity when cigarette ash from 5 cigarettes was extracted in $25 \mathrm{ml}$ Tris- $\mathrm{HCl}$ buffer, $\mathrm{pH} 8.0$, or dilute $\mathrm{HCl}$ whose $\mathrm{pH}$ was later readjusted to 8.0. Similarly, ash from 60 cigarettes extracted with $50 \mathrm{ml}$ water failed to show DCIP reducing activity. Ashing of an ethanol extract of cigarette smoke condensate also resulted in loss of all DCIP reducing activity. These results rule out DCIP reducing activity by inorganic substances in cigarette smoke or tobacco extract and suggest that organic combustion products are responsible.

\section{Comparison of Cigarette Brands}

It has been reported (3) that, for cigarette smoke, reducing activity parallels the yield of particulate matter. Our experiments using moist TPM have shown that this does not always hold and that reducing activity is dependent to some extent on the tobacco type in the cigarette. If the oxidation state of the condensates were expressed as specific activities the majority of flue-cured cigarette brands gave similar values, while blended brands containing other tobaccos in addition to flue-cured gave a lower value (Table 2). Statistical analysis of the results show that the fluecured and blended brands are significantly different and that any differences between the brands within the 2 groups can be explained by within sample variation.

The type of filter does not appear to have any effect on specific activity. Filtration decreases total activity per cigarette but the parallel decrease in TPM leaves specific activity unaltered.

Smoke from an experimental cigarette made of 100\% reconstituted tobacco showed lower specific activity but smoke from a cigarette made of $100 \%$ stem was of the same order as the standard. A ventilated cigarette gave smoke with considerably lower reducing activity (Table 3 ).

\section{Comparison of Cigarette, Cigar and Pipe \\ Tobacco Smoke Condensates}

Condensates from cigar and pipe smoke were tested for reducing activity towards both cytochrome $c$ and

Table 3. Reducing activities of condensates from special types of clgarettes.

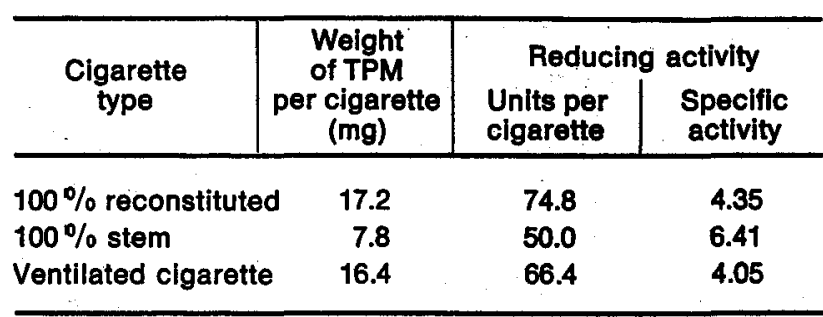


Table 4. Reducing actlvitles of clgarette, clgar and plpe TPM (dried).

The figures represent the mean of at least 5 replicates.

\begin{tabular}{|c|c|c|c|}
\hline \multirow{2}{*}{$\begin{array}{c}\text { Condensate } \\
\text { from }\end{array}$} & \multirow{2}{*}{ TPM (mg) } & \multicolumn{2}{|c|}{ Reducing activity } \\
\hline & & $\begin{array}{l}\text { Total } \\
\text { units }\end{array}$ & $\begin{array}{l}\text { Specific } \\
\text { activity }\end{array}$ \\
\hline Cigarette & 16.4 & 108.3 & 6.60 \\
\hline Cigar & 32.3 & 45.0 & 1.39 \\
\hline Pipe & 29.7 & 33.4 & 1.13 \\
\hline
\end{tabular}

Table 5. TPM ylelds for different periods of pipe-smoking.

\begin{tabular}{|c|c|c|c|}
\hline \multirow{2}{*}{$\begin{array}{c}\text { Time } \\
\text { (mins.) }\end{array}$} & \multirow{2}{*}{$\begin{array}{c}\text { Tobacco burned } \\
\text { (mg) }\end{array}$} & \multicolumn{2}{|c|}{ TPM (mg) } \\
\hline & & Wet & Dry \\
\hline 1 & 79 & 7.8 & 7.7 \\
\hline $\begin{array}{l}3 \\
5\end{array}$ & $\begin{array}{l}236 \\
316\end{array}$ & $\begin{array}{l}21.9 \\
24.8\end{array}$ & $\begin{array}{l}14.5 \\
20.0\end{array}$ \\
\hline 10 & 500 & 57.3 & 39.6 \\
\hline 20 & 811 & 169.6 & 66.6 \\
\hline
\end{tabular}

DCIP. It was found, however, in pipe-smoking that considerably larger amounts of water accumulated on the Cambridge filter than that occurring during smoking of cigars or cigarettes. Consequently, for intercomparison of condensates from the three different smoking vehicles it was necessary to dry all the filter pads over sodium hydroxide in an evacuated desiccator at $4^{\circ} \mathrm{C}$. This procedure did not result in any significant loss of activity.

In this series of experiments dry TPM from 7 brands of flue-cured cigarettes were tested for reducing activity with DCIP. Specific activities with a mean of 6.60 were obtained. Dry TPM from 5 brands of cigars when similarly analysed gave markedly lower specific activities with a mean of 1.39. Dry TPM from pipe smoke also produced low specific activity, mean 1.13 (Table 4).

The wider range of results which was found for pipe tobacco TPM, can be attributed to the erratic nature of pipe-smoking. Intermittent relighting was necessary and the amount of tobacco burned was not always proportional to time, particularly at shorter burn periods. Typical experimental results are shown in Table 5.

With the limitations of pipe-smoking in mind a brief study was made of the reducing activity of condensates from cigarette and cigar tobaccos smoked in a pipe. The former gave the same specific activity as pipe tobacco TPM, while the latter showed virtually no reducing properties.

\section{Distribution of Reducing Activity Between Particulate and Vapour Phase}

For cigarette smoke it was found that the reducing activity of particulate matter was 20 to 30 times greater than that of vapour phase. These results are in general agreement with those of Hagopian (3) who quoted a figure of 10 to 1 . We have failed, however, to observe
Table 6. Distribution of reducing actlvity between particulate and vapour phases.

The figures represent the mean of at least 5 replicates.

\begin{tabular}{l|c|c|c}
\hline \multirow{2}{*}{$\begin{array}{c}\text { Condensate } \\
\text { from }\end{array}$} & \multicolumn{2}{|c|}{ Reducing activity } & \\
& $\begin{array}{l}\text { Units in } \\
\text { TPM }\end{array}$ & $\begin{array}{c}\text { Units in } \\
\text { VP }\end{array}$ & TPM/VP \\
\hline Cigarette & 108.3 & 4.9 & 22.1 \\
Cigar & 45.0 & 10.1 & 4.4 \\
Pipe & 32.5 & 4.2 & 7.7 \\
\hline
\end{tabular}

the ratio of $3: 1$ reported by the same author for smoke from a cigarette with a very efficient filter for particulate matter. In our hands a brand with such a filter gave the same ratio as cigarettes with ordinary filters. An explanation of these conflicting results may lie in the fact that Hagopian collected TPM from up to one cigarette while we did so from 5 cigarettes on the same Cambridge filter.

Similar experiments with cigar and pipe smoke showed that the ratio of reducing activity of particulate phase to that of vapour phase was considerably lower than that for cigarette smoke (Table 6).

\section{CONCLUSIONS}

On the basis of our results it can be concluded that dye-reducing activity does not provide a means of differentiating between condensates from standard market brands of cigarettes. It can, however, be used to distinguish cigarettes with radically different formulations, such as those made from reconstituted tobacco or those with ventilation. An additional area where the reducing property offers valuable information is in measuring the oxidation state of condensates from tobacco smoked in different vehicles. The biological significance of dye-reducing activity of condensates has not yet received much attention but it is intended to try to correlate this property with existing biological tests.

\section{SUMMARY}

Condensates obtained by smoking cigarettes, cigars and pipe tobacco have been compared on the basis of their abilities to reduce cytochrome $c$ and DCIP. Most market brands of flue-cured cigarettes, while differing on the basis of total reducing activities, give similar values when reducing activity is expressed as specific activity (reducing activity per $\mathrm{mg}$ particulate matter). Condensates from blended cigarette brands containing other types of tobacco in addition to fluecured, have lower specific activities.

Special types, such as cigarettes made from $100 \%$ reconstituted tobacco and a ventilated cigarette, also give lower values. Both cigars and pipe tobaccos give condensates with distinctly lower specific activities than those obtained from flue-cured cigarettes. In the case 
of pipe tobacco a large amount of water accumulates on the Cambridge pads and has to be taken into account when calculating specific activities.

\section{RESUME}

Les condensats obtenus en fumant des cigarettes, des cigars et du tabac à pipe ont été comparé en vertu de leur capacité de reduire le cytochrome c et le D.C.I.P. La plupart des marques commerciales de cigarettes faites de tabac jaune quoique différant dans leur activité réductrice totale, donnent cependant des valeurs équivalentes si l'activité réductrice est exprimée en activité spécifique (activité réductrice par $\mathrm{mg}$ de matière particulaire).

Les condensats provenant de marques de cigarettes contenant d'autres types de tabac ajoutés au tabac jaune ont des activités spécifiques plus basses.

Des cigarettes de type spécial, telles que celles à $100 \%$ tabac reconstitué ou ventillées, donnent aussi des valeurs plus basses. Les cigars et le tabac à pipe donnent des condensats ayant des activités spécifiques distinctement plus basses que celles obtenues pour les cigarettes à tabac jaune. Dans le cas du tabac à pipe, une grande quantité d'eau s'accumule sur le filtre Cambridge et ceci doit être pris en considération dans le calcul des activités spécifiques.

\section{ZUSAMMENFASSUNG}

Rauchkondensate von Cigaretten, Zigarren und Pfeifentabak wurden nach ihrer Fähigkeit, Cytochrom-c und DCIP zu reduzieren, miteinander verglichen. Bei den meisten der marktgängigen Cigaretten aus röhrengetrodknetem Tabak ist die Reduzierfähigkeit der Kondensate insgesamt ziemlich unterschiedlich; ausgedrückt als spezifische Aktivität (Reduzierfähigkeit je mg Partikelphase) ergeben sich dagegen für die meisten Cigarettenmarken ähnlide Werte. Bei Kondensaten aus Cigaretten, die neben röhrengetrocknetem Tabak auch noch andere Tabake enthalten, findet sich eine verminderte spezifische Aktivität. Dies gilt auch für die Kondensate von Cigaretten aus Tabakfolie $(100 \%)$, von
Cigaretten mit perforiertem Papier und von Cigaretten mit zwei verschiedenen Arten von Kombinationsfiltern. Bei Kondensaten aus Zigarren und aus Pfeifentabak ist die spezifische Aktivität merklich geringer als bei denen der Cigaretten aus röhrengetrodkneten Tabaken. Beim Abrauchen von Pfeifentabak sammelt sich auf den Cambridge-Filtern ein beträctitlicies Volumen Wasser an, das bei der Berechnung der spezifischen Aktivität berücksichtigt werden muß.

\section{REFERENCES}

x. Benedict, R. C., Strange, E. D., and Lakritz, L.: 23rd Tobacco Chemists' Research Conference, Philadelphia, Penn., 1969.

2. Benedict, R. C., Lakritz, L., Strange, E. D., and Stedman, R. L.: Chem. \& Ind., 13 June 1970, 800.

3. Hagopian, M.: Environ. Sci. Technol. 3 (1969) 567.

4. Hagopian, M., and Rosenkrantz, H.: Proc. Soc. Exp. Biol. Med. 130 (1969) 1234.

5. Margoliash, E., and Frohwirt, N.: Biochem. J. $7 x$ (1959) 570.

6. Schultz, F. J., and Spears, A. W.: Tobacco 162 (1966) 32.

7. Shmuk, A. A.: Izvest. Akad. Nauk., U.S.S.R., Biological Division, 1939, 955.

8. Sloan, C. H., and Sublett, B. J.: Tobacco Sci. 9 (1965) 70 .

9. Sober, H. A. (ed.): Handbook of biochemistry Selected data for molecular biology, Cleveland, Ohio, The Chemical Rubber Co., 1968, p. J 29.

10. Wickham, J. E., Westbrook, J. J., and Holmes, J. C.: Tobacco Sci. 6 (1962) 50.

\section{Adknowledgements}

The authors wish to thank Mrs. C. Fletcher for skilled technical assistance.

The author's address:

Research Department,

Imperial Tobacco Products Limited,

P.O. Box 6500, Montreal - 101, Quebec, Canada. 